\title{
THE GOOSE FLIGHT OF WESTERN IOWA
}

\section{By JACK W. MUSGROVE**}

Of the many wildlife spectacles to be found the world over, it is doubtful whether any surpasses in magnitude and sheer wild beauty the spring flight of blue and snow geese in western Iowa, along the broad alluvial flood plain of the Missouri river. This area, scenic and historic in itself, is bordered by rugged loess bluffs, where centuries ago wind deposited layer upon layer of fine earth. Into this compact soil, water has cut almost vertically, leaving sheer walls which at a distance appear to be miniature mountains, clothed in coarse blue stem, studded with drought-resisting yucca, and still showing the deeply worn trails left by the American bison. Between these bluffs flows the sprawling muddy Missouri with its shifting sand bars and rank growths of willow slaps.

In all probability this area has been the migration route of blue and snow geese for centuries, but until recent years it has remained almost unnoticed, and the lives of these birds have been clothed in mystery. This migration was unmentioned by early naturalists-Audubon, Lewis, and others-who came to this area and probably missed one of the most magnificent spectacles ever to greet the eyes of man.

During the last few years the long pilgrimages of these birds have been unraveled, and their flights charted from the wintering grounds on the gulf coasts of Louisiana and Texas to the breeding grounds on the arctic tundra of Baffin Island, where winter winds and grinding ice greet them on their arrival in mid-June. Their nesting grounds are inaccessible places seldom visited,

* Jack W. Musgrove is Director of the State Museum, in the Iowa State Department of History and Archives, and author of "Waterfowl in Iowa," "Birds of Iowa Pioneer Days," "Market Hunting in Northern Iowa," and numerous scientific articles. 
nor would they be as spectacular as the sight to be seen on the western border of Iowa during the spring migration.

Early in March, often while ice remains on the ponds and streams, with snow drifts partly covering the hills and filling the ditches, come the first arrivals of blues and snows. So anxious are they to move northward that the first flocks follow on the heels of retreating winter, often to be forced back temporarily by severe weather.

Advancing, they are joined in a few days by countless thousands which gather in huge flocks or concentrations, covering the fields or marshes where they have chosen to stop.

To visit the birds in this area is to see a sight never to be forgotten. It is within the reach of thousands of people; is accessible by means of hard-surfaced roads, yet only during the last few years have people awakened to the possibility of the enjoyment and recreation to be had within a few day's drive of their homes. Formerly only those living in the locality, and passengers on trains crossing the Missouri bottoms, were aware of the magnificent flight. Naturalists from many parts of the country now visit this flight annually, and late years have seen more and more motorists stopping along the roadsides to view the thousands of blue and snow geese resting, feeding, or in flight in this scenic area. It is something to look forward to. Anyone who has ever witnessed this sight will find himself drawn back year after year by the magnetic, irresistible call of the "waveys." The raw March winds sweep cold and wet across river flats and marshes, the wet gumbo clings in great balls to the observer's feet, yet it is possible to shut out both cold and damp by dressing warmly, and armed with binoculars, telescope, or cameras, one is prepared to watch the huge concentrations of geese which arrive every year between the 10th and 25th of March.

Within a short driving distance of several large towns are vantage points from which the flocks may be viewed. 
One can observe them congregated in tightly packed groups, watch them as they take off to feed in the morning, and hear the clamor of their voices as they swirl and mill in the air, going to some nearby corn field to feed on waste grain. Their feeding activities can be seen readily, as they swarm over the ground, literally piling over each other, working through the fields, and cleaning up what remains of last year's crop. Temporarily satisfied, small groups return in a short time to the concentration, to be replaced by others, shuttling back and forth between the resting and feeding grounds. Long lines and waving formations arise from the fields, small groups and individuals, many with balls of black gumbo and weeds still cling to their feet.

\section{VIEW MAJESTIC Flights IN AIR}

High in the sky overhead, at times barely distinguishable, will be seen traveling flocks, irregular V-formations, large V's breaking into smaller ones, all overlapping and stretching for miles. Some of these flights continue northward; others pass the concentration, then as if by some prearranged signal, break formation, swing and sideslip or tumble like falling leaves, losing altitude rapidly, and alight with the resting flock. As these new arrivals drop from the sky they extend their necks, throw back their wings and dangle their coral-pink legs, light gracefully, take but two or three steps to break the momentum, and find room to settle in a flock that appeared so densely packed there was room for no more. As their numbers increase, the spongy ice of the lake sinks beneath the combined weight of many thousands of birds.

Here one may watch these birds resting and preening and see the beautiful rust stains on their heads, the territory to France, "with the same extent that it now variations. Among the blues are young birds of last season's hatch, with dark heads only lightly flecked with white; others with more mature plumage, showing considerable white on their heads; and the veterans of many mi- 
grations with the white of their necks running down to the shoulders. There are those which show the plumage characteristics of both blues and snows, blotched and piebald in appearance, in all likelihood hybrids. Nor is variation in plumage limited to the blues, for the snow geese exhibit a variety of water stains, younger birds still show grayish plumage on their necks and bodies, and rarely a bird is snow white except for its jet-tipped wings. Close observation will reveal that the blues outnumber the snow geese about twenty to one.

Among the flocks in the air will be small groups or lines of white-fronted geese with their speckled bellies, and occasional V's of the largest of American geese, the Canada. In spite of their similar size, the white-fronts are easily distinguished from the blues and snows by their laughing calls, their slender build, narrow wings, and stiff-necked manner of flying. Often they break their formations over the concentrations of blue and snow geese, side-slipping, twisting, darting, and gaining momentum at low altitudes over the mass of geese, but seldom alighting with them, choosing instead a resting spot at one side of the concentration. With their sedate flight, glistening black necks, and broad wings, the Canada resemble gigantic bombers among their smaller cousins. Occasionally one is privileged to see the rare Hutchin's, bantam of the goose family, short and chunky in appearance but minature Canadas in behavior. Through the flocks of geese dart small bunches of ducks, dwarfs in comparison, with rapid wing beats and interrupted flight-pintails in their courtship flights, several longnecked, graceful males performing aerial acrobatics for the benefit of a single female; green-winged teal with their high-pitched, shrill quacking and darting flight; baldpates with their shrill whistles, swinging low over the marshes and fields; mallards, already paired; redheads with their soft, mewing calls; American mergansers with bright crimson legs, contrasting black and creamy-white plumage and stiff manner of flight. 
Not long do the flocks stay at rest. The approach of an airplane or of someone trying to get nearer for a picture frightens them and they take to the air in a dense swarming mass which resembles a plague of locusts, with a deafening roar of wings and clamoring voices. Silhouetted against the sky, they present one of the most striking sights imaginable. The sparkle of snow geese against the blue sky lends enchantment, and it is difficult to believe that there could have been so many birds on the lake. They soon will return to rest, but each milling activity attracts new flocks; small groups may take off for more northern destinations and hardly be missed.

During the afternoon the feeding performance will take place again, but the best part of the show is yet to come. As the sun drops below the horizon and the sky is painted with every shade of crimson, orange, and lavender, the birds return to their resting grounds, and silhouetted against the flaming sky comes the evening flight of the "waveys." Long lines, broken V's, and small flocks- like strings of beads in the sky-come lazily in. Even after darkness has settled the birds still come, more and more until one may think there is no end.

Returning home hours later with the clamor of their voices still ringing in one's ears, one realizes that no other sight compares with this. Days. spent in the duck-blind were enjoyable ones, but looking back over years of hunting, fishing, and other types of recreation, the time spent among these geese, with only camera or binoculars for armament, has been the most memorable. There is no closed season on observation or photography; no bag limits are imposed, nor is any license necessary. Nothing could be more of a challenge to the photographer, be he amateur or professional. All are on an equal basis, and although a few years ago these roadways were littered with cartridge boxes, now one finds only empty film containers, mute witnesses to the fact that someone has enjoyed the geese to the fullest by recording memories which will abide with him for years to come. 


\section{Flight MEMoRABLE}

The flight during the spring of 1947 developed into one of the largest concentrations ever seen in this area. Bad weather prevented the birds from moving north, and they congregated on the Forney lake area of Fremont county until by rough estimate, the birds in this concentration numbered at least a half million. Single photographs of a very small portion of this flock may show ten thousand or more geese. The scene attracted cameramen, outdoor writers, naturalists, scientists, and people from all walks of life. Many commented on the number of birds and the beauty of the sight, and one old sportsman now in his eighty-sixth year remarked, "It's funny that it took me eighty years to realize a person can enjoy birds in other ways than looking down the barrel of a shotgun."

The migration through Iowa is usually leisurely, with the timing depending, of course, upon weather conditions. The flight usually lasts three to four weeks, the first birds coming during the early part of March and the large concentrations generally occurring about the 15th. Areas where the birds are feeding will be inhabited by these large flocks for several days, after which the bulk of them will move northward to the next spot at which they congregate. The first arrivals usually land on the bottom lands west of Hamburg, Iowa, moving shortly to an area near Percival or to Forney lake. In a few days they appear at Kellogg's slough, an area south of Glenwood, going on to Green and Manawa bottoms south of Council Bluffs, with some continuing to Honey Creek lake and Noble's lake. There will be small concentrations near Modale in an area known as the Slaps and others near Piver Sioux on the Missouri river itself. This area, while not too popular with the geese, is a paradise for other types of waterfowl. The next large concentrations will be near the Onawa-Turin area or around Grant Center. The last great concentration in Iowa will be in the Hornick-Luton area south of Sioux 
City. Many of these areas will hold large concentrations every year but changing conditions may alter resting and feeding grounds. As a general rule, however, small groups and scattered flocks containing from 500 to 10,000 geese are to be found throughout the entire area.

The birds leave the Missouri river near Sioux City, most of them following the Big Sioux river into Minnesota and South Dakota, from there to the marshes near Winnipeg, Manitoba, on to James bay, and into the Arctic to their nesting grounds. For years blue geese disappeared into the Arctic and their exact breeding grounds remained unknown. J. Dewey Soper, working under the Department of Interior, Ottawa, Canada, discovered the nesting grounds of these birds June 26, 1929, on the great western tundra of Baffin island, in a narrow strip of coastal plain along the eastern shore of Bowman bay, Foxe basin. In 1930 Dr. George M. Sutton discovered still other blue geese nesting on Southampton island in Hudson bay, several hundred miles west of these discovered by Soper; and Angus Gavin of the Hudson Bay Company in 1940 found two pairs of blue geese nesting on a tributary of the Perry river. The 3,000-mile flight from their wintering grounds in Louisiana to their breeding range requires about 11 weeks, the birds arriving at the nesting grounds in mid-June.

In the fall, blue geese leave their breeding grounds the first part of September, coming down the eastern coast of Hudson bay and congregating on the extensive salt marshes of Hannah bay at the extreme south end of James bay. Early in October, the southbound flight moves rapidly toward its destination in Louisiana and does not cover the route taken by the spring migration. Although few blue geese are seen over the entire flyway in the fall, during the last few years increasing numbers have been stopping in this state, particularly around the middle of October, and at times they have been hunted with some success. Formerly the blue goose was very rare in the fall, almost all of the birds passing over 
at high altitudes in a non-stop flight. 'This pattern of flight has allowed the species to maintain its numbers, with few being killed during the fall flights except those taken by the Indians at Hudson bay and by hunters and trappers on the wintering grounds in Louisiana. Blue geese have few natural enemies and if their winter range is well protected, should continue to delight the eye of the naturalists and sportsmen of this country.

\section{CUMMINS AS AN IOWA ORATOR}

It remains for the biography of Albert B. Cummins to be prepared and published. His colorful career was closed in July 1926 when he was at the zenith of his power and usefulness to the state and the nation. Sketches and brochures have all agreed in giving him high place as a forceful and convincing speaker, an able advocate at the bar, an effective campaigner. $\mathrm{He}$ was also one of the great orators of Iowa, and at times there came flashing from his tongue a series of brilliant sentences that fairly captivated the hearers.'

As evidence of his real oratorical ability it may be considered proper to reprint an address delivered by Senator and Governor Cummins made long before he had ever been induced by his friends to enter the political arena. The occasion was a bar banquet in honor of Judge John Mitchell when he retired from twelve years on the district bench, in Des Moines, the date being Dec. 30, 1880. Mr. Cummins, then a practicing young lawyer, less than three years residing in Des Moines, spoke for the bar of Polk county in presenting a token of their esteem of the retiring judge. The gift was a set of books, the Lives of the Lord Chancellors, and also other additions to the judge's fine library. The address of Lawyer Cummins is here reprinted from the Iowa State Register for its intrinsic worth as a model of oratory:

Mr. Chairman: As members of the Polk County Bar we are already saying one to another, "The King is dead. Long live the 
Copyright of Annals of Iowa is the property of State of Iowa, by \& through the State Historical Society of Iowa and its content may not be copied or emailed to multiple sites or posted to a listserv without the copyright holder's express written permission. However, users may print, download, or email articles for individual use. 